TECHNICAL TRANSACTIONS 12/2018

ENVIRONMENTAL ENGINEERING

DOI: $10.4467 / 2353737$ XCT.18.185.9673

SUBMISSION OF THE FINAL VERSION: 15/10/2018

\title{
Michał Grodecki
}

\author{
Aleksander Urbański (D) orcid.org/0000-0002-5544-9134 \\ aurbansk@pk.edu.pl \\ Department of Geotechnics, Faculty of Environmental Engineering, Cracow University \\ of Technology
}

LANDSLIDING SLOPE SUPPORTED BY GABIONS -

A CASE STUDY AND THE METHODOLOGY OF NUMERICAL MODELLING

ZABEZPIECZENIE OSUWISKA MUREM OPOROWYM Z GABIONÓW PRZYKŁAD ZASTOSOWANIA I METODYKA ANALIZY KOMPUTEROWEJ

\footnotetext{
Abstract

The paper presents results of numerical analysis of the gabion retaining wall stability. A few of the possible design variants were analyzed and the optimal one was chosen.

Keywords: gabion, retaining wall, FEM, stability
}

\section{Streszczenie}

Praca przedstawia rezultaty analiz numerycznych stateczności muru oporowego z gabionów. Przeanalizowano możliwe warianty projektowe i wybrano optymalne.

Słowa kluczowe: gabion, mur oporowy, MES, stateczność 


\section{Symbols}

$\phi \quad-$ internal friction angle $[\mathrm{deg}]$

$\gamma$ - soil bulk density $\left[\mathrm{kN} / \mathrm{m}^{3}\right]$

c - cohesion $[\mathrm{kPa}]$

SF - stability factor $[-]$

\section{Introduction}

The landslide which is analysed in this work is localised in a sub-mountain area of southern Poland, near the city of Nowy Sącz. It is located at lower parts of slopes of a V-shaped valley. At the valley floor a stream runs, which normally carries minimal flow (less than 0.5 cubic metre/ $\mathrm{sec})$, but it temporarily grows up to several cubic metres per second. Exact hydrological data were not available; however, evidence of such events in the past was visible, along the banks of the stream. Erosion related to this was the most probable cause of landslide activation, endangering the municipal road crossing it. Signs of massive movements were observed, both as the deterioration of the road surface and terrain deformation. In order to protect the road, and to fix the problem of stream bank strengthening, a gabion retaining wall is proposed. Also ecological and landscape preservation issues were taken into account

The whole landslide has a length of about $300 \mathrm{~m}$, but the length of its lowest part, protection of which is considered here, is of $60 \mathrm{~m}$. Remaining parts of the road crossing the landslide was protected by other structural means (Tessina-wall).

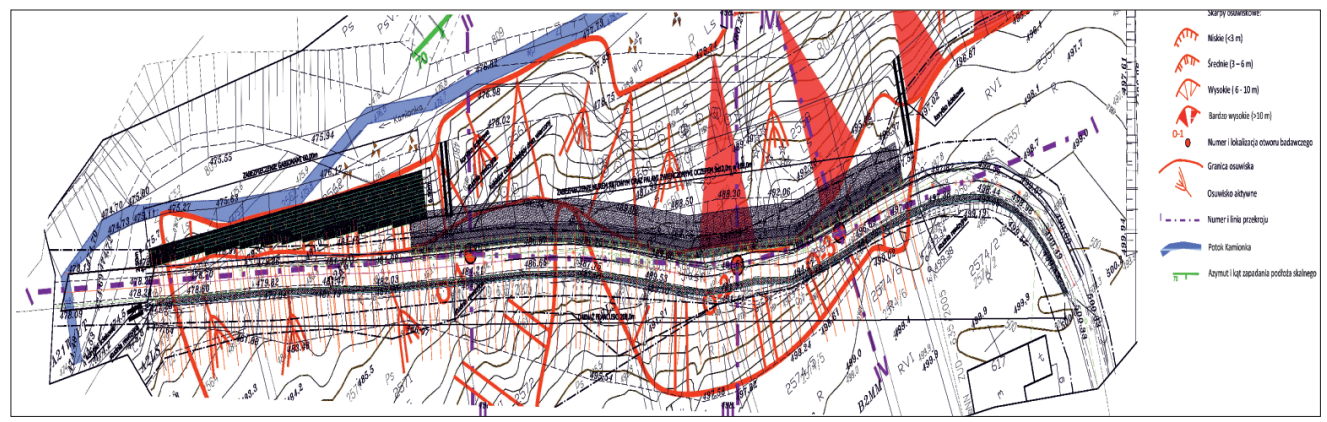

Fig. 1. Situation of the landslide area (gabion wall at the left, marked dark)

The design history and the possible construction variants (especially the final one) analysed are described. Special attention is paid to numerical analysis, which was used to perform static calculations (in order to check stability conditions of the landslide and estimate internal forces in structural elements).

The height of the slope beneath the road reaches $7.5 \mathrm{~m}$, so it looks quite possible to construct a gabion retaining wall as a protective structure.

According to existing geotechnical evidence, the existing slope is built mostly from weak clays (cohesion $c$ about $11 \mathrm{kPa}$, internal friction angle $\phi$ about $11^{\circ}$ ). Rocks with compressive 
strength $f_{c}$ about $0.36 \mathrm{MPa}$ are found at about $4 \mathrm{~m}$ below the terrain level, stronger rock (with $f_{c}$ about $0.78 \mathrm{MPa}$ ) $-6 \mathrm{~m}$ below the terrain level. A load of $25 \mathrm{kPa}$ due to road traffic was introduced at the municipal road according to Polish legal regulations [8].

\section{Numerical simulations}

Numerical simulations were performed using ZSoil v16 code. The c- $\phi$ reduction method (described in [5-7]) was used to estimate Stability Factor SF. All simulations were performed in the plane strain conditions. The Coulomb - Mohr elastic-plastic model was used for the soil. The soil-water composite was treated as a single-phase media, mainly because the geotechnical documentation, which was prepared prior to the author's involvement in the case, only contains data allowing for this kind of approach. For gabions (made of $60 \times 80 \times 3.3 \mathrm{~mm}$ wire mesh and filled with crushed aggregate), the Coulomb-Mohr model with additional cohesion (described in [2], parameters estimated with use of mesh strength parameters according to $[1]$ ) was used. Interface elements between gabions and soil and between gabions were used. Interface parameters were estimated according to [3] (friction angle between gabions and between gabions and subsoil equal to $90 \%$ of the internal friction angle) and [4] (cohesion in the interface elements responsible for the limited tensile strength of the joints between gabions estimated as $20 \mathrm{kPa}$ ). The truss elements responsible for modelling of the joints between gabions resistance to gap opening were used, with tensile strength of the joints of $20 \mathrm{kN} / \mathrm{m}$ (see [4] for details).

Table 1. Parameters of the gabion and soil used in the stability analysis

\begin{tabular}{|l|c|c|c|c|}
\hline \multicolumn{1}{|c|}{ Material } & $\begin{array}{c}\mathbf{E} \\
{[\mathbf{M P a}]}\end{array}$ & $\gamma\left[\mathbf{k N} / \mathbf{m}^{3}\right]$ & $\begin{array}{c}\phi \\
{\left[{ }^{\circ}\right]}\end{array}$ & $\begin{array}{c}\mathbf{c} \\
{[\mathbf{k P a}]}\end{array}$ \\
\hline I (uncontrolled embankment) & 100 & 21.0 & 20 & 5 \\
\hline II (silty clay + rubble) & 13 & 22.5 & 11 & 11 \\
\hline IVa (clay rubble) & 15 & 21.5 & 12 & 12 \\
\hline Va (rubble) & 400 & 24.0 & 55 & 57 \\
\hline VI (soft rock) & 500 & 24.0 & 55 & 123 \\
\hline Gabions $h=1 \mathrm{~m}$ & 200 & 22.0 & 40 & 30.75 \\
\hline Gabions $h=0.5 \mathrm{~m}$ & 200 & 22.0 & 40 & 61.5 \\
\hline Concrete & 24000 & 24.0 & - & - \\
\hline
\end{tabular}

First of all, a stability analysis of the existing "in situ" state of the slope was performed (numerical model - see Fig. 2). The value of the stability factor SF $=1.028$ obtained (without road load) shows that slope is practically in the limit state of the stability (Fig. 4). So design of the protecting structure was really necessary. 


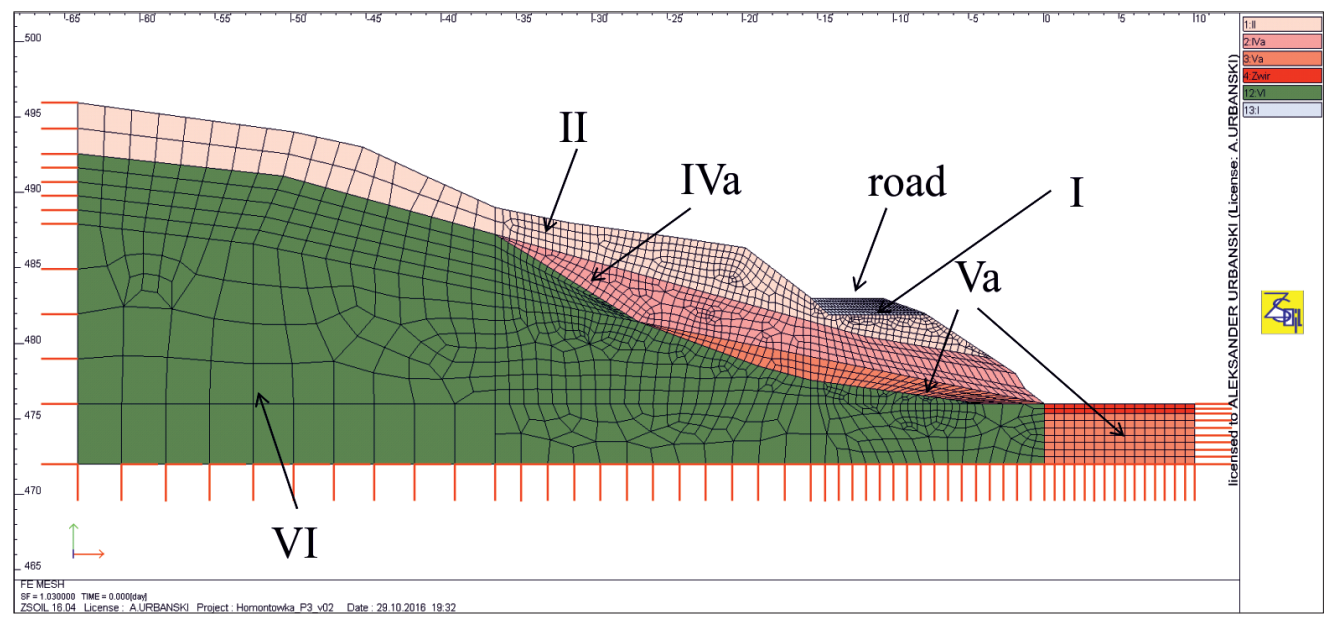

Fig. 2. Numerical model of the existing landslide

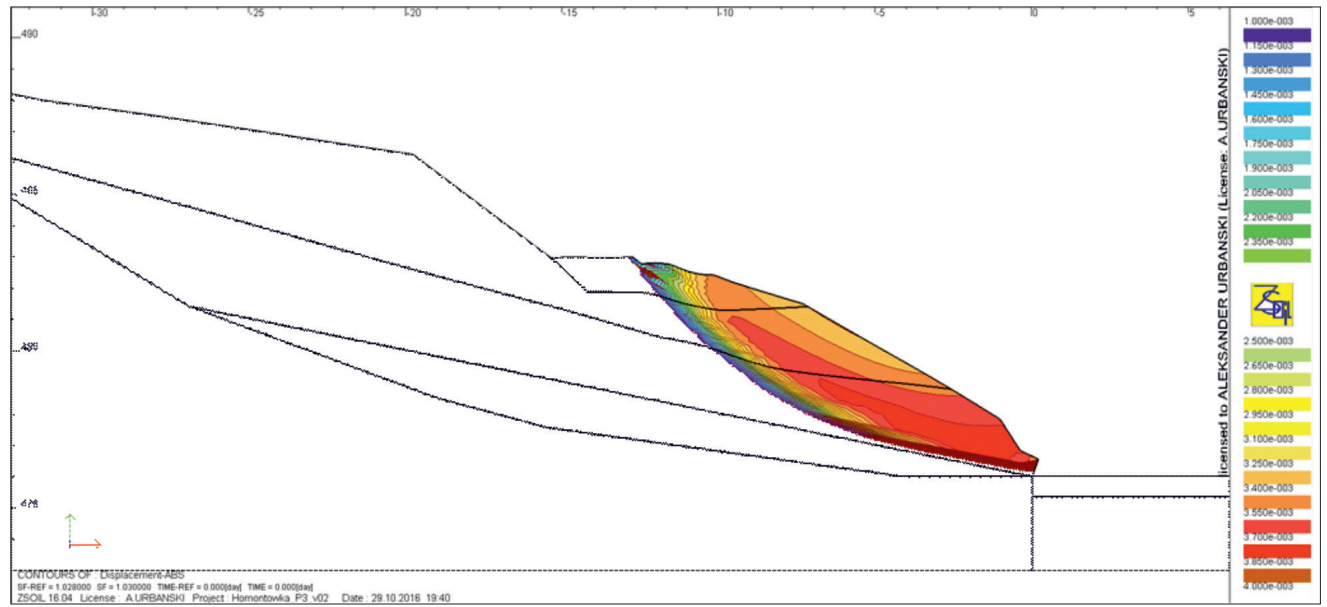

Fig. 3. Failure mode (sliding surface) of the existing landslide, $\mathrm{SF}=1.028$

The first variant of the gabion wall consists of one $1 \mathrm{~m}$ high and eleven $0.5 \mathrm{~m}$ high gabions. Numerical simulation shows that such a construction does not improve the stability of the landslide ( $\mathrm{SF}=1.01$ without road load). It's worth noticing that the destruction mode of this variant includes lowest gabion failure due to shearing. So taking into account the limited shear strength of the gabions is essential for safe design.

In order to obtain a satisfactory value of SF, about 1.50, anchoring of the wall was analysed. Titan 40/20 type anchors with $90 \mathrm{~mm}$ drilling tool diameter were used. An anchoring length of $12 \mathrm{~m}$ (including $5 \mathrm{~m}$ active zone), distance between anchors of $5 \mathrm{~m}$ and prestress $\sigma_{0}=20 \mathrm{MPa}$ was applied.

Firstly, one anchor level was proposed (Fig. 5) and an SF = 1.20 (Fig. 6) with road load was achieved. So anchoring of the gabions wall leads to some increase of the SF, but the result obtained is still not satisfactory. 


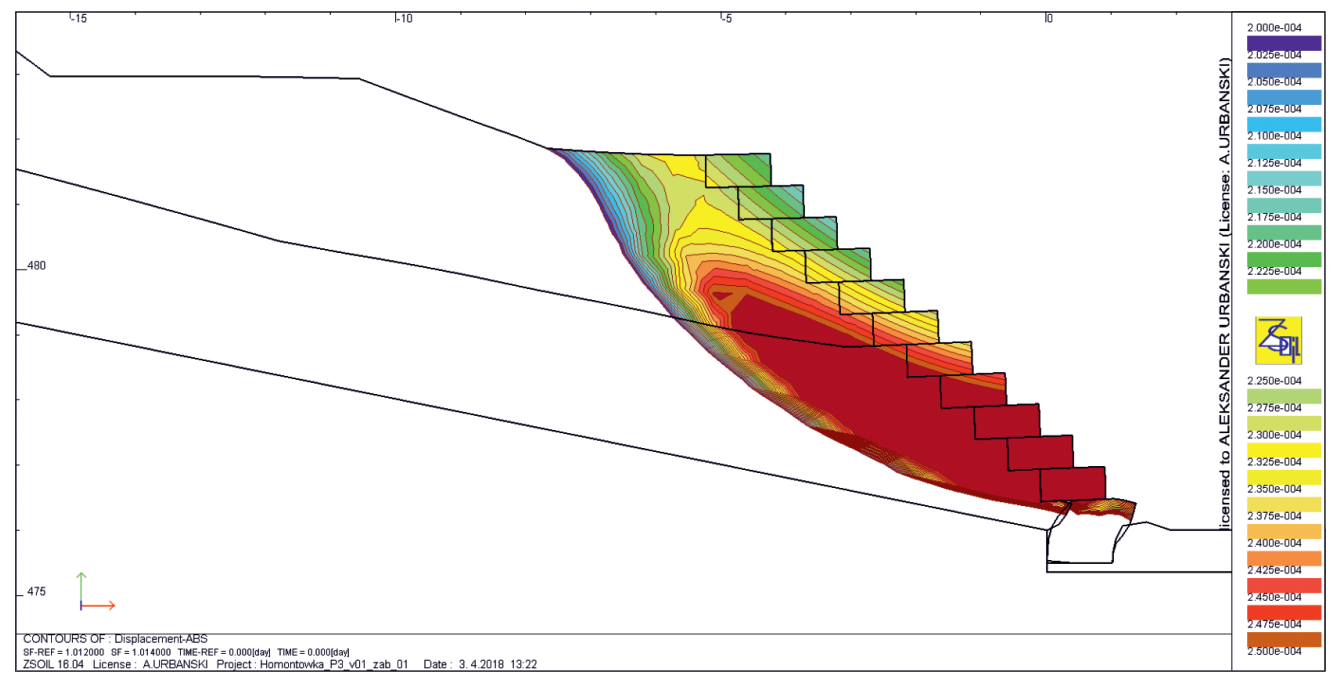

Fig. 4. Failure mode (sliding surface) of the landslide supported by gabions without anchors, $\mathrm{SF}=1.01$

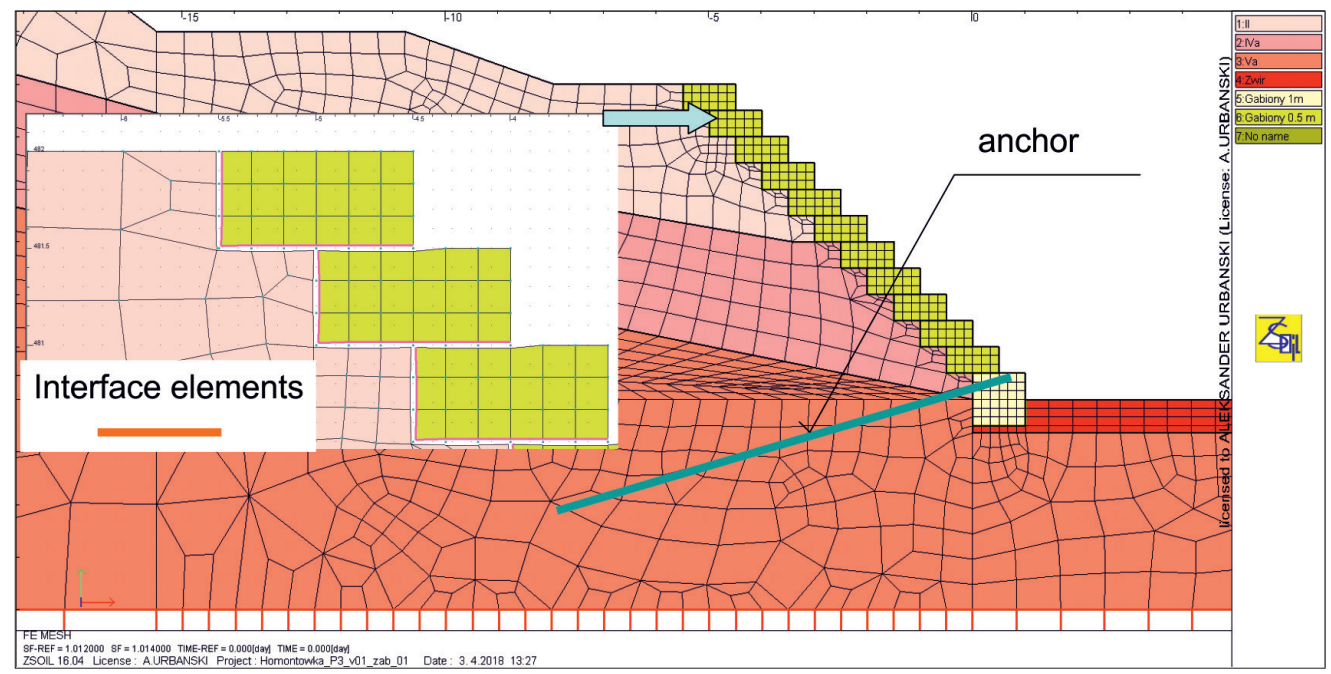

Fig. 5. Numerical model of the gabions wall with 1 level of anchoring. Detail of gabions modelling

Two levels of anchors results in an SF $=1.26$ (with road load), which is still not satisfactory.

Finally, a variant with 4 levels of anchors was proposed and a satisfactory SF $=1.63$ (with road load) was achieved.

This variant was chosen as the optimal one and selected for realisation. One important detail is the way of strengthening the gabion surface in a situation where large forces from the anchors are introduced, by means of a continuous reinforced concrete beam (section $0.3 \mathrm{x}$ $0.5 \mathrm{~m}$ ), placed on the anchor levels. This is shown in drawings (Fig. 8). 


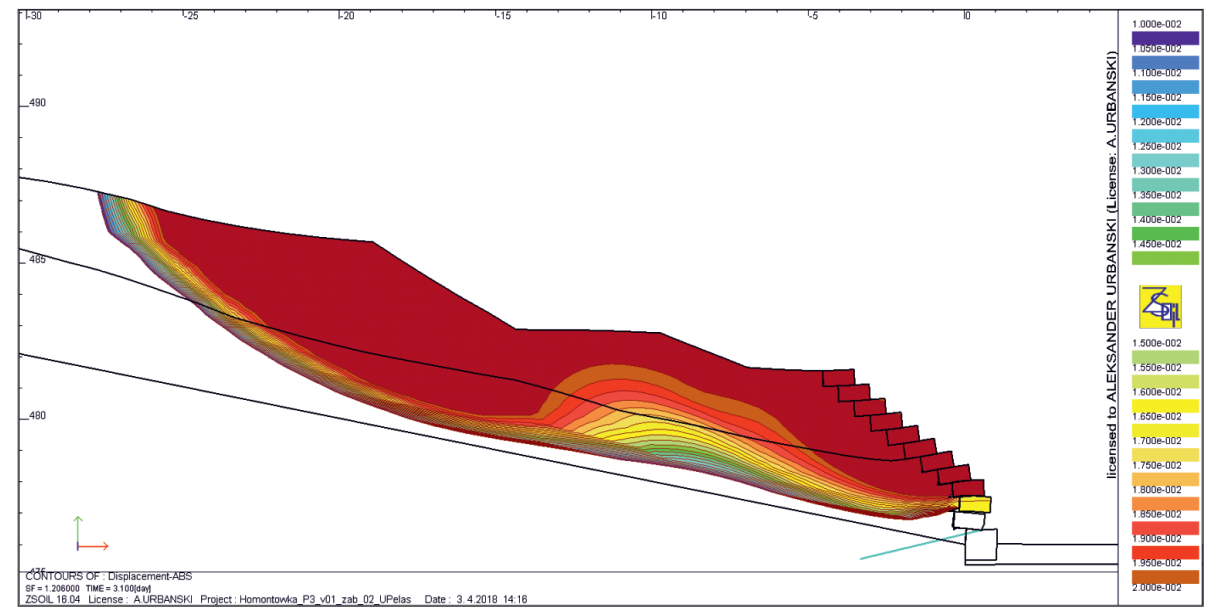

Fig. 6. Failure mode (sliding surface) of the landslide supported by gabions with 1 anchor level, $\mathrm{SF}=1.20$

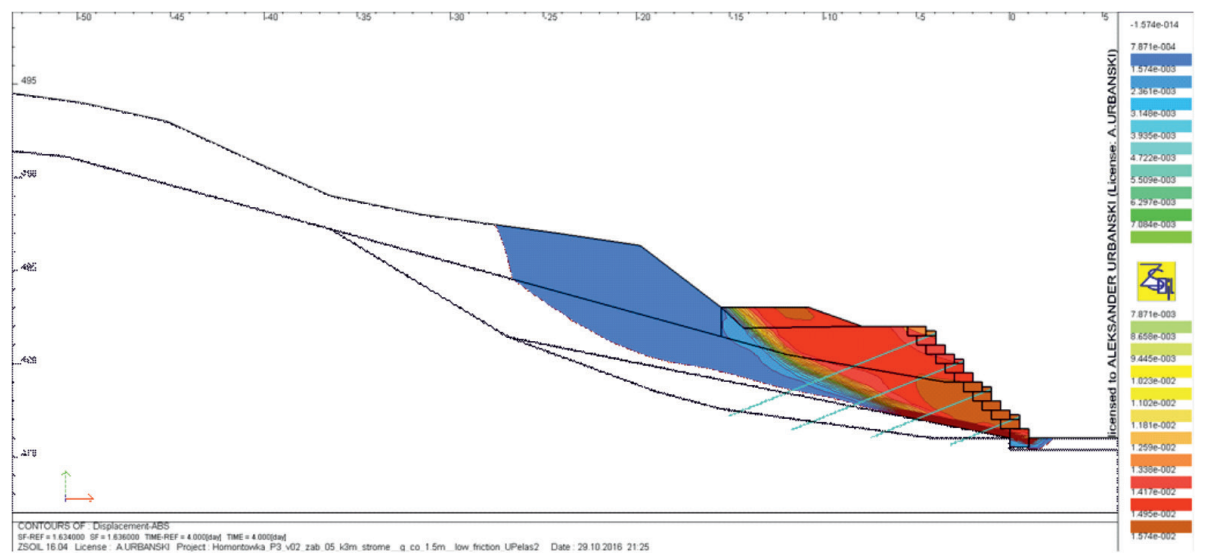

Fig. 7. Failure mode (sliding surface) of the landslide supported by gabions with 4 anchor level, $S F=1.63$

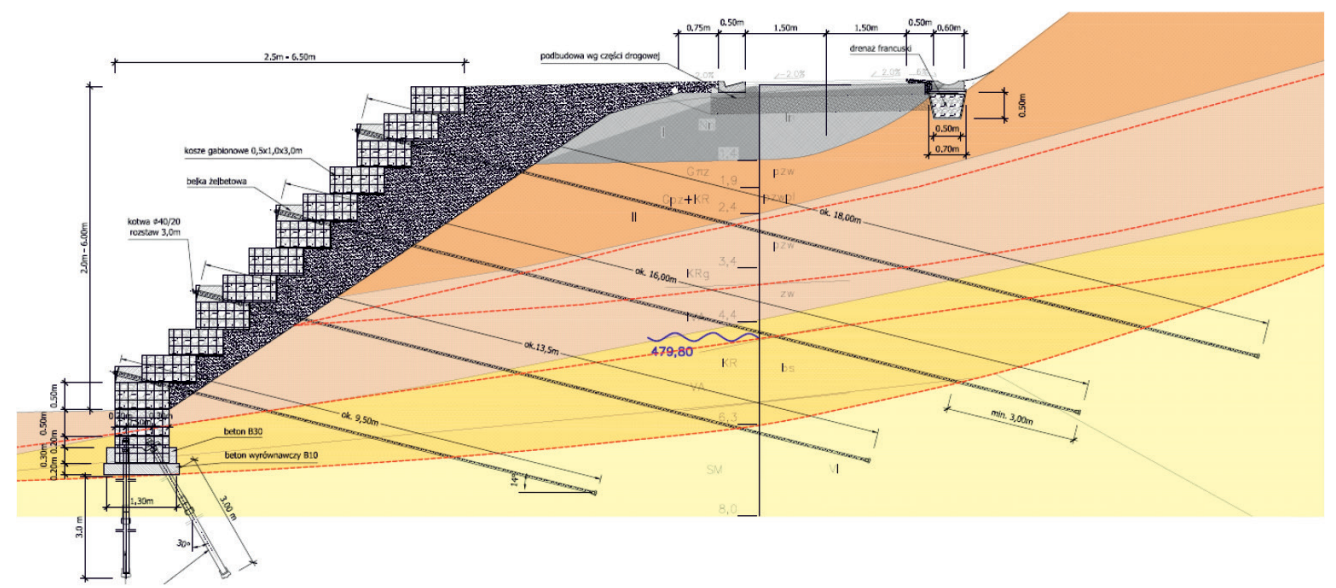

Fig. 8. Final structural solution of anchored gabions securing the roads. 


\section{Final remarks}

The numerical simulations of the landslide protected with gabions presented show that such simulations could be a useful tool in the design process. It was possible to analyse several variants of the structure and to choose the optimal one. It's worth noticing that in some cases stability loss occurs with shearing of the gabions or failure of the connection between gabions. Therefore, the limited shear strength of the gabions and limited joints strength should be taken into account.

\section{References}

[1] A 975 - 97 Standard Specification for Double-Twisted Hexagonal Mesh Gabions and Revet Mattresses (Metallic-Coated Steel Wire or Metallic-Coated Steel Wire With Poly(Vinyl Chloride) (PVC) Coating), American Society for testing and materials, 2011.

[2] Bathurst R.J., Rajagopal K., Large-scale triaxial compression testing of geocell reinforced granular soils, "Geotechnical Testing Journal” Vol. 16, No. 3/1993, 296-303.

[3] Bergado D.T., Youwai S., Teerawattanasuk C., Visudmedanukul P., The interaction mechanism and behavior of hexagonal wire mesh reinforced embankment with silty sand backfill on soft clay, "Computers and Geotechnics" 30/2003, 517-534.

[4] Grodecki M., Numerical modelling of gabion joints, “Technical Transactions” 2/2017, 83-89.

[5] Griffiths D.V., Lane P.A., Slope stability analysis by finite elements. "Geotechnique" 49/1999, 387-403.

[6] Matsui T., San K-C., Finite element slope stability analysis by shear strength reduction technique. "Soils and Foundations" 32/1992, 59-70.

[7] Zimmemann Th., Truty A., Urbański A., Podleś K., Z_Soil.PC 2003 manual. Theory, Elmepress international \& Zace Services ltd., Lauzanne, Switzerland 2005.

[8] Rozporządzenie Ministra Transportu i Gospodarki Morskiej z dnia 2 marca 1999 r. w sprawie warunków technicznych, jakim powinny odpowiadać drogi publiczne i ich usytuowanie. Dz.U. 1999 nr 43 poz. 430. 